towards the cost. Two large experimental plants were erected at the factory in Shropshire during the summer of 1935 . In one plant, the waste waters, after sedimentation, are treated by the activated sludge process (Fig. 1) operated in a manner similar to that adopted for the treatment of sewage at sewage disposal works. In the other plant (Fig. 2), the settled waste waters are submitted to biological oxidation in two percolating filters in series, and the order of the filters is reversed at intervals of ten days to three weeks. Each filter contains hard metallurgical coke, graded 0.75-1.5 in. Both plants have been in continuous operation since their erection in July 1935 , in the treatment of milk washings and mixtures of milk washings and whey washings. For the activated sludge process, the settled crude waste is diluted, if necessary, to give a mixture parts per 100,000 parts. From this mixture a final effluent with a biochemical oxygen demand of less than 1 part per 100,000 parts is obtained, even with the high rate of treatment of 240 gallons a day per cubic yard of filtering medium in the two filters together, that is, $\mathbf{4 8 0}$ gallons a day per cubic yard in each filter. This is a rate of treatment much greater than that usually adopted in the treatment of domestic sewage at sewage disposal works in Great Britain. Tests over long periods have shown that trout are able to live in the undiluted final effluents from the experimental plants.

Of the two methods investigated for the treatment of milk effluents, the process of biological filtration with two filters in series and periodic change in the order of the filters appears to be the more suitable for operation under factory conditions. To allow a margin of safety, the diluted

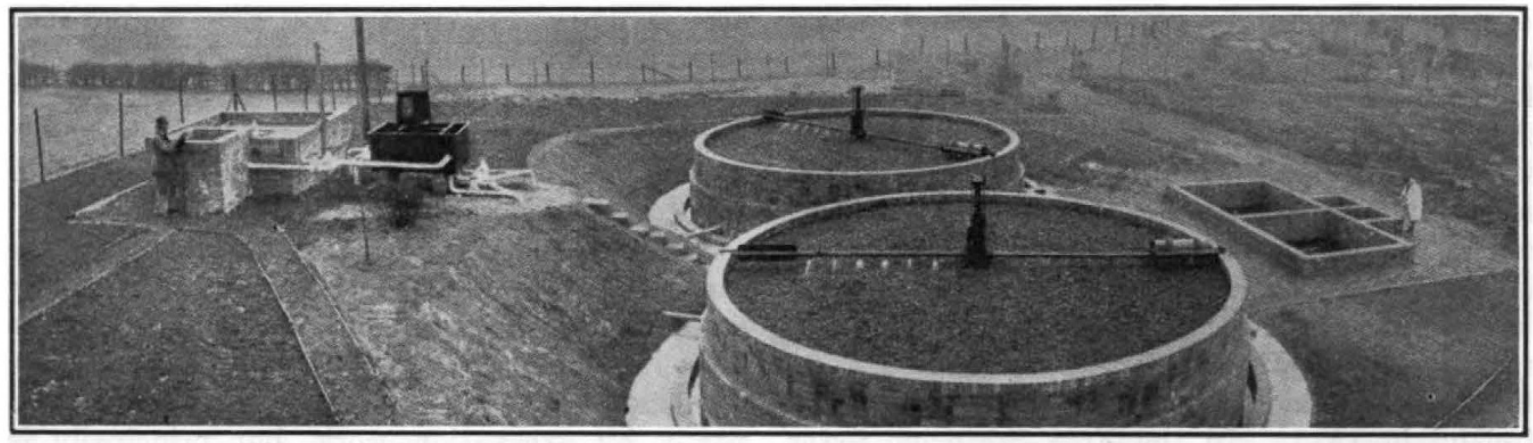

Fig. 2.

Experimental plant for the treatment of Milk effluents by blological filtration with two FILTERS IN SERIES.

Reproduced by permission of the Controller, H.M. Stationery Office; Crown copyright reserved.

with a biochemical oxygen demand of not more than 50 parts per 100,000 parts. From this mixture, with a period of aeration of twenty-four hours, a final effluent with a biochemical oxygen demand of about 1 part per 100,000 is obtained. For the biological filtration plant, the settled wastes are diluted to give a mixture with a biochemical oxygen demand of not more than 30 settled crude liquid should be supplied to the filters at a rate not greater than 160 gallons a day per cubic yard of filtering medium in the two filters together. Daring the past two years, several plants designed on the basis of the experimental filtration plant have been erected at depots and factories in different parts of the country, and other similar plants are in course of construction.

\title{
New Aspects and Problems in Irish Archæology*
}

$\mathrm{T}$ HE acquisitions of new archæological material by the National Museum of Ireland now represent a yearly increase forty times larger than that of ten years ago. The old-established collection of Irish antiquities contains an unusually high percentage of unlocalized or ill-localized specimens; but the National Museum is now

* Substance of the presidential address for 1937 by Dr. Adolf Mahr to the Prehistoric Society. Proc. Prehist. Soc., 3, 2, pp. 262-436 +7 plates $(1937)$. building up a second collection, each object accurately located, which at least in numerical strength compares with the old one and will serve as a basis for distributional studies.

During the past five years, large-scale systematic excavations have been undertaken, which have contributed to the clarification of at least some of the most hotly contested problems in the archæology of Ireland. No comprehensive survey 
of Irish archæology, however, can as yet be made, though this may be possible in ten years time. Five years' excavation has merely touched the fringe of the problems before us.

Recent progress in the conception of Irish archæology is in no small measure due to the fact that protective legislation of national monuments is now bearing fruit. The respective administrative and advisory organizations of the Free State and of Northern Ireland co-operate freely ; and the archæological activities of the Royal Irish Academy and of the Royal Society of Antiquaries of Ireland are fully all-Irish in character.

No systematic excavation worthy of the name had been undertaken for many years. The opportunity to make a fresh start came with the proposal of Dr. B. H. O'Neill Hencken for the Harvard University Archæological Expedition to Ireland, which as part of a larger scheme of anthropological investigation in Ireland, excavated for five years in succession, from 1932 until 1936. Sites of a size never attempted before were then excavated, not with the object of collecting antiquities, but purely with the aim of obtaining scientific evidence. It taught Ireland scientific methods of excavation, and trained Irish workers in technique. In 1934 the Free State's scheme for the relief of unemployment opened the way to systematic excavation on an unprecedented scale, and a similar measure was adopted in Northern Ireland in 1935. In the Free State, no fewer than twenty-six excavations have been carried out, many extending over more than one season, and nearly all devoted to sites of outstanding importance. Irish, English, American and Danish archæologists have participated in the work. In addition, 'licensed' excavations have been carried out by the learned societies and private individuals.

In the most important department of the correlation of all evidence available, little work has been done. The Belfast Field Naturalists' Club in 1930 set about launching a cartographical survey of monuments, archæological sites and antiquities generally in Northern Ireland, of which the preparation was entrusted to Miss M. Gaffikin. In 1935 two distribution maps were published, one of megalithic monuments, the other of raths, cashels and crannogs. Some six hundred megalithic monuments have been listed, and some two thousand of the later monuments ; but the authors disclaim completeness.

Physical anthropology has been neglected for so long in Ireland that Prof. C. P. Martin's book "Prehistoric Man in Ireland" is an almost unhopedfor achievement. His work is being continued by Prof. I. K. Jamieson, of Trinity College, Dublin.

Investigation of the problems of the peat, the most important source of Irish archæological material, was begun by Prof. G. Erdtmann in his studies of pollen analysis (1928), and is being continued by Prof. K. Jessen, of Copenhagen, and the Committee for Quaternary Research in Ireland. Important, if at present tentative, conclusions, based on evidence from sixty sites, as to late glacial and early post-glacial events and chronology have already emerged, while conclusions of a like tentative character as to climatic change at the beginning of the Late Bronze Age, when correlated with similar phenomena in north-western Europe, by placing this phase of the cultural succession in Ireland at a period some centuries later than that accepted by archæologists, opens up an important field for further investigation.

It was from work such as these bog investigations, from the large-scale excavations, and from the ancillary activity in the National Museum offices that the modern conception of Irish archæology arose and recent progress is due. Four major results stand out, of which three are due to excavation work: These are : first, as a result of excavations in Northern Ireland, the history of an almost forgotten but important megalithic monument, the horned cairn, with its derivatives, is now clear; secondly, it is known that the souterrain, as a type, can be as old as the Middle Bronze Age ; thirdly, at least one crannog, that of Knocknlappa, Co. Clare, belongs to the Late Bronze Age, in other words, antedates the La Tène period : and fourthly, partly by excavation work, but principally by analysis and comparison of museum material, a hitherto unobserved cultural facies, the Riverford lithic civilization, has been recognized.

Dr. Mahr proceeded to discuss the evidence for the existence of the stone culture to which he has given the name of the 'Riverford civilization' and its relation to the stone cultures of Britain and northern Europe, and then turned to a critical and constructive examination of the fresh evidence bearing, more especially in relation to the European background, on the palæolithic and mesolithic periods, the neolithic period, megaliths, their derivation and distribution, megalithic art, the Bronze Age, and the early Iron Age. In summing up an analysis of the 'Keltic' problem, in which he follows a line of argument reverting more or less to the position on the $p$ and $q$ problem of Sir John Rhys, Dr. Mahr outlines the general conclusions of the archæological evidence as follows:

We have been able to trace the following immigrations or invasions into Ireland. (1) A mesolithic stratum. Probable source: the western continent. Route : south Britain. (2) Another lithic stratum, the Riverford people, or the Picts. Ultimate source: Maglemose culture somewhere around Denmark. Route : Doggerbank-ScotlandHebrides. (3) The Megalithic invasion, heralding 
the Bronze Age. About 2100 B.c. Source: Iberia. Route : Brittany-Cornwall-Irish Sea. (4) The Late Bronze Age invasion. About 900 B.c. Source : Middle (and Lower ?) Rhine and eastern, plus northern France. Route : Lowland BritainCumberland-Wigtownshire. (5) The La Tène wave. About 200 or 150 B.c. British Kelts coming from Wigtownshire occupied only a limited district of north-eastern Ireland.

Of these, (3) was certainly a non-Aryan movement. Much of the non-Indo-Germanic traits of ancient Ireland must be due to it. (4), however, came from a region in which the Kelts were deeply rooted. It was probably the Keltic cradle ; while (5) was an aristocratic conquest by bands, who came apparently without their womenfolk.

In reference to the aims of future research, one thing stands out clearly. The rigid canons of European prehistory are applicable to Ireland only with considerable qualification. They hold good so far as the general sequence goes, but some periods culturally so far outweigh others as almost to eclipse them. The only cultural strata in Ireland which really matter are (1) the basically 'lithic' Riverford complex; (2) the megaliths, and the earlier part of the bronze age they signify; (3) the Late Bronze Age (and the Kelticization of the country it brought about); and (4) the Early Christian period. There are periods in which Ireland has an importance for all Europe quite out of proportion to its size, and others in which she is simply an appanage of Britain.

The international importance of Irish archæology is too well known to be stressed here. Its importance for British archæology is, if anything, even greater. The only area of western Europe which was never Romanized, not only contains the clue to all problems of free Caledonia, but Roman Britain, too, is not intelligible without the Keltic background, which can be unfolded by research in Ireland. No problem in Irish archæology can be solved without the British evidence; but is there any problem in British archæology which can be solved without Irish evidence?

\section{Tenth International Congress of Chemistry}

$\mathrm{T}$ HE Tenth International Congress of Chemistry met in Rome on May 15-21. More than thirty nations sent representatives, two thousand eight hundred in all ; they included about seven hundred from Germany, two hundred from France and seventy-five from Great Britain.

Proceedings were opened at the Capitol in the presence of His Majesty the King of Italy with an address on the "Conquests of Chemistry" delivered by the president of the Congress, His Excellency Prof. N. Parravano of the University of Rome, and this was followed later by a reception by the Minister of National Education in the stadium of the Palatine-two sites of impressive and historic dignity.

The business of the Congress was conducted in the fine modern rooms of the recently built Citta Universitaria, in which the large hall set apart for the meetings was filled to overflowing during the opening addresses of the various sections.

Among those who opened the sections were Prof. P. Walden, on "The Creed of Scientific Chemistry"; Prof. C. N. Hinshelwood, on "Physical Chemistry and Modern Scientific Thought", delivered in fluent Italian; Prof. Swietosławski, on "Developments of Industrial Chemistry"; Prof. Jolibois, on "Transformation of Matter and Motive Power" ; Prof. Giordani, on "The Utilisa. tion of Thermal Energy"; Prof. Votocek, on
"Synthesis of Carbohydrates"; Dr. Hissink, on "The Chemistry of Soils"; Dr. L. M. Lampitt, on "The Trend of Food Science"; Prof. E. von Euler, on "Vitamins and Hormones in Food and in the Human Organism"; Prof. Ruggli, on "Housing, Furnishing and Clothing in their Chemical As. pects" ; Prof. Viviani, on "Natural and Artificial Textiles"; Prof. Fourneau, on "The Progress of Therapeutic Chemistry"; Prof. Butenandt, on "New Problems in Biological Chemistry"; Prof. Seyewetz, on "Chemistry and Photography"; Dr. S. E. Sheppard, on "Optical Sensitising of the Silver Halides"; Dr. Fr. ter Meer, on "New Developments in Chemical Technology"; Prof. G. Egloff, on "Petroleum-its Chemical and Industrial Significance"; Prof. D. M. T. Bogert, on "Chemistry and Defence"; Prof. H. Mark (not present) on a similar subject; Prof. Fr. Fischer, on "Chemistry and the Motor"; and Prof. Portevin, on "Metallurgy in Transport".

The President's opening speech and summaries of the above addresses in various languages were collected in a small volume and distributed at the end of the Congress, while in La Chimica $e$ l'Industria for May $(20,251 ; 1938)$ will be found notes on the very numerous individual contributions to the sections together with photographs and short biographies of the presidents, vice-presidents and opening lecturers of each section. 